\title{
Food service compliance with ISO 14001 and ISO 22000
}

\section{Cumprimento das normas ISO 14001 e ISO 22000 por serviços de alimentação}

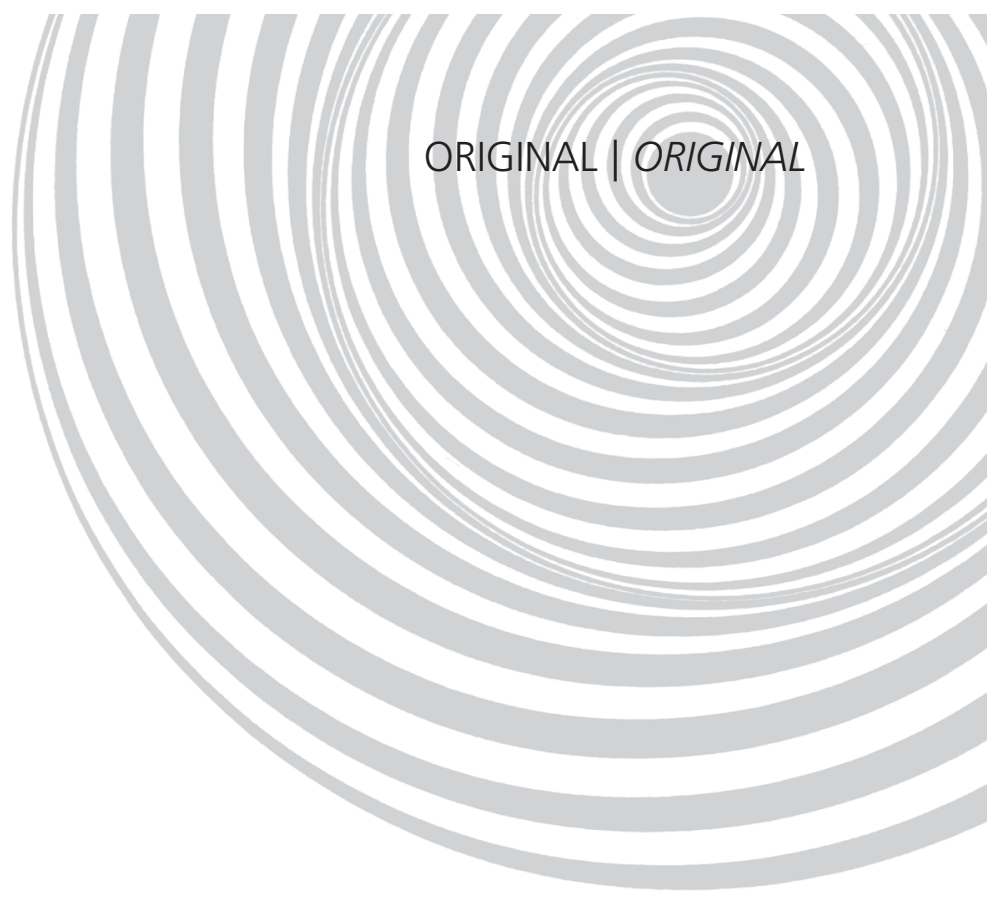

Laura Lyra SANTOS 1

Rita de Cássia Coelho de Almeida AKUTSU²

Raquel Braz Assunção BOTELHO²

Renata Puppin ZANDONADI ${ }^{2}$

A B S T R A C T

\section{Objective}

The objective of this study was to assess food service environmental and food safety management systems according to two checklists based on ABNT ISO 22000 and 14001.

\section{Methods}

This exploratory and descriptive study investigated a-la-carte food services of the Federal District, Brazil. Two checklists were developed to investigate ISO 14001 and 22000 compliance. A total of 37 food services were selected from the list of the Brazilian Association of Bars and Restaurants by simple random sampling. Checklist results were analyzed according to ANVISA resolution $n^{\circ} 275 / 2002$.

\section{Results}

Only five food services employed dietitians to supervise meal production. These establishments achieved the highest ISO compliance. However, no establishment had more than 50\% ISO 14001 or 22000 compliance. Restaurants showed little concern for the environment and disobeyed waste disposal laws by not separating recyclables from non-recyclables.

\section{Conclusion}

The study food services do not have safe meal production systems, evidenced by non-conformity with the reference standards. Additionally, they do not attempt to reduce the environmental impact of their wastes. Food services supervised by dietitians are better prepared to produce safe foods.

Indexing terms: Environmental impact. Food security. Food services. ISO 14001. ISO 22000.

${ }^{1}$ Universidade de Brasília, Centro de Excelência em Turismo. Brasília, DF, Brasil.

2 Universidade de Brasília, Faculdade de Ciências da Saúde, Departamento de Nutrição. Campus Darcy Ribeiro, Asa Norte, 70910-900, Brasília, DF, Brasil. Correspondence to/Correspondência para: RCCA AKUTSU. E-mail: <rita_akutsu@yahoo.com.br>. 
374 | LL SANTOS et al.

\section{RE S U M O}

\section{Objetivo}

Avaliar, em estabelecimentos produtores de refeições, a segurança de alimentos e a preocupação ambiental de acordo com o cumprimento das normas ABNT ISO 22000 e 14001 por meio de dois checklists.

\section{Métodos}

O presente estudo exploratório e descritivo foi realizado em restaurantes a la carte do Distrito Federal. Foram elaborados dois check-lists para representar os requisitos das normas ISO 22000 e 14001. Determinaram-se estatisticamente 37 unidades produtoras de refeições participantes, que foram sorteadas aleatoriamente dentre as presentes na lista da Associação de Bares e Restaurantes. Os resultados dos checklists foram analisados de acordo com os critérios de pontuação da Resolução ANVISA n 275/2002.

\section{Resultados}

Cinco unidades possuíam nutricionista como responsável técnico e foram as que obtiveram maior conformidade no check-list da ISO. Nenhuma das unidades atingiu mais de 50\% dos requerimentos das ISO 14001 e 22000 , o que mostra a falta de preocupação com as questões ambientais e o não cumprimento da legislação vigente sobre coleta seletiva de lixo.

\section{Conclusão}

As unidades pesquisadas não possuem uma produção de refeições segura, conforme estabelecido nas normas de referência, e não se dedicam a diminuir o impacto ambiental gerado por seus resíduos poluentes. As unidades que têm um nutricionista apresentaram-se em melhores condições de produzir alimentos seguros para a população.

Termos de indexação: Impacto ambiental. Segurança alimentar e nutricional. Serviços de alimentação. ISO 14001. ISO 22000.

\section{INTRODUCTION}

In food services, quality is associated with intrinsic aspects of the food (nutritional composition), safety (sanitary and hygienic conditions), service (customer-supplier relationship), and price. Sanitary and hygienic conditions have been widely studied and discussed as food safety factors, since foodborne illnesses are among the main causes of death in some countries ${ }^{1}$.

Greater industrialization and opening of the markets to competition promoted many changes to the food sector, both with regard to production and marketing. After some hygienerelated events and environmental disasters that occurred in the end of the 1990s, a wave of food scandals - methanol in wine, salmonella in eggs, lead in powdered milk, benzene in water increased concern for sanitary quality, expanding the concept of food safety. These incidents did not only increase consumer awareness of food safety, but also had immediate and severe economic repercussions in the countries involved ${ }^{2}$.
Food sanitation should concern everyone since contaminated foods may cause serious health effects.

Good Manufacturing Practice (GMP) is a set of regulations, codes and guidelines for the manufacture of certain items, including food products, beverages and materials that are in direct contact with foods to assure quality ${ }^{3}$.

Good Manufacturing Practice is a critical prerequisite for the implementation of Hazard Analysis and Critical Control Points (HACCP), which is considered part of the measures required for food safety and a reference for the creation of laws that regulate on food production ${ }^{3}$. Instead of detecting foodborne pathogenic microorganisms at the end of the production process, HACCP is effective because it minimizes contamination by introducing critical control points in the production process 4 .

Globalization has encouraged consumers to demand better product quality as well as universal parameters to ensure this quality ${ }^{5}$. Attributes such as hygiene, quality, sustainability 
and reliability have become essential for consumers' decision on whether to purchase a product or service. To meet these demands, the productive sector felt the need to implement systems that improved quality monitoring, quality control and sanitation, and reduced environmental impact $^{5,6}$.

Most countries have food safety and environmental impact laws, like the Denmark regulations (DS 3027) and British retail consortium. However, ISO standards are being used together with local standards since the former are acknowledged internationally and allow the comparison of studies from different countries ${ }^{7}$. In 1947, the first ISO standard was issued, ISO 9000. In 2005, another ISO standard was issued, ISO 22000, and a year later, ISO 14000.

Implementation of ISO 22000 is one way to monitor food production. This standard is specific for the food chain and an excellent instrument for restaurants, as it allows production monitoring and introduces the concept of traceability ${ }^{8}$.

This instrument is divided into five parts regarding the Food Safety Management System (FSMS): (1) food safety system requirements; (2) food safety management requirements; (3) food safety resource requirements; (4) food safety execution requirements and (5) food safety confirmation requirements. It is fit for all organizations, regardless of size, and is critically important for companies that seek third-party acknowledgment or certification of their food safety management system ${ }^{9}$.

Likewise, ISO 14001 is divided into six parts: system requirements, policy requirements, planning requirements, operational requirements, checking requirements and review requirements. ISO 14001 aims to provide a strategic approach for the organization's environmental policy, plans and actions. One of its achievements is the establishment of a common reference for organizations to communicate about environmental management ${ }^{10}$.
The two abovementioned ISO standards cover all the recommendations and regulations set forth by GMP and HACCP. In addition to HACCP, the two ISO standards introduce the concept that organizations should follow written instructions and write down everything they do. This principle is the core of the standards. Documents are not only important, they must be followed ${ }^{9,10}$.

Certification is essential for global acknowledgment, traceability and responsibility. In Brazil, the market is growing and becoming international. Many international events will be held in the country in the next few years and certified companies with recognized standards will be more competitive.

A checklist is a concise way of analyzing compliance with these regulations and recommendations. This tool allows a preliminary assessment of food service hygiene, sanitary conditions and environmental practices. It can be used for assessing human resources, environmental conditions, facilities, sanitation, sanitization, equipment, production, packaging, labeling, quality control and market control ${ }^{11}$.

This initial assessment can reveal critical non-conformity points and aid in the development of measures that increase facility, procedure and productive process efficacies, eliminating or reducing physical, chemical and biological hazards that may compromise the products and consumer health ${ }^{11}$.

The objective of this study was to use two checklists based on the ISO 22000 and 14001 standards to assess conformity of a-la-carte restaurants in Brasilia with the Food Safety Management System (FSMS) and Environmental Management System (EMS).

\section{METHODS}

This is an exploratory, descriptive study of a-la-carte restaurants in Brasilia. Two checklists covering the eleven abovementioned sections of 
ISO 22000 and 14001 were developed. The checklists were then reviewed as described by another study ${ }^{12}$, that is, ten experts were asked to assess their clearness, accurateness, applicability and suitability for food services.

A-la-carte restaurants were chosen because of their preprocessing and mealdistribution characteristics, and because there is a scarcity of data in the Brazilian literature on environmental and food safety management in this type of food service. Simple random sampling was used for selecting the restaurants from the Brazilian Association of Bars and Restaurants of Brasilia member's list ${ }^{13}$.

The standard deviation of five daily meals was estimated statistically. An estimation of a simple random sample of 37 a-la-carte restaurants was based on a population of 58 a-la-carte restaurants, a sampling error of one (1) daily meal and a significance level of $5 \%{ }^{14}$.

This research was approved by the Universidade de Brasilia Research Ethics Committee, protocol number $087 / 2008$. The inclusion criterion for the 37 selected restaurants was accepting the terms of the study and signing a free and informed consent form.

Checklist data was collected by interviewing supervisors, employees and/or owners and direct observation. Table 1 shows examples of some items in the checklists.

The score was based on compliance: Group 1 (G1): compliance with 76 to $100 \%$ of the items in the checklists; Group 2 (G2) compliance with 51 to $75 \%$; Group 3 (G3) compliance with 0 to $50 \%$. The restaurants were also classified as small, medium-sized and large according to number of meals, which is the criterion used by the Brazilian Department of Labor and Employment ${ }^{15}$. The data were treated statistically and analyzed descriptively to assess the environmental and food safety management systems of the study food services.

Association between education level and compliance was assessed by the Mantel-Haenszel linear association test ${ }^{16}$. Association between presence of a dietician and compliance was assessed by the Mantel-Haenszel mean score test. The significance level was set at $5 \%(p<0.05)^{16}$.

Table 1. Example of items present in the ISO 14001 and ISO 22000 checklists. Brasilia (DF), Brazil), 2010.

\begin{tabular}{|c|c|c|c|c|}
\hline \multirow{2}{*}{$\begin{array}{l}\text { Items } \\
\text { Environmental Policies - ISO14001 }\end{array}$} & \multicolumn{3}{|c|}{ Responses } & \multirow[b]{2}{*}{ Observations } \\
\hline & Yes & No & D.A. & \\
\hline \multicolumn{5}{|c|}{ The organization has an established environmental policy. } \\
\hline \multicolumn{5}{|c|}{$\begin{array}{l}\text { This environmental policy is appropriate to the nature, scale and environmental impact } \\
\text { f your activities, products or service. }\end{array}$} \\
\hline Objectives, goals and programs & Yes & No & D.A. & Observations \\
\hline \multicolumn{5}{|c|}{$\begin{array}{l}\text { The organization establishes implements and maintains environmental objectives and goals } \\
\text { documented in the functions and levels of the organization. }\end{array}$} \\
\hline \multicolumn{5}{|c|}{$\begin{array}{l}\text { The organization establishes implements and maintains programs that include the ways } \\
\text { and time for them to be achieved. }\end{array}$} \\
\hline Food safety system - ISO 22000 & Yes & No & D.A. & Observations \\
\hline \multicolumn{5}{|c|}{ The unit evaluates frequently the food safety system. } \\
\hline \multicolumn{5}{|c|}{ The unit delegates part of its responsibility in the food safety system to other organization. } \\
\hline Comunication & Yes & No & D.A. & Observations \\
\hline \multicolumn{5}{|c|}{$\begin{array}{l}\text { The organization established implemented and maintained effective methods to } \\
\text { communicate to suppliers and hires. }\end{array}$} \\
\hline There are records of these communications. & & & & \\
\hline
\end{tabular}




\section{RESULTSAND DISCUSSION}

The following data were collected from each restaurant: number of menu items (small, medium-sized, large), number of meals, number of shifts, education level of the supervisor, and presence of a full-time dietitian.

All 37 restaurants were classified as small ${ }^{15}$. None of the restaurants had a simple menu, 13 (35.0\%) had medium-sized menus, 17 (46.0\%) had medium-to-executive menus and 7 (19.0\%) had executive menus. Only 5 restaurants (13.5\%) had only one working shift.

The education level of the supervisor of 9 restaurants $(24.3 \%)$ was elementary school, of 23 restaurants $(62.1 \%)$ high school and of 5 restaurants (13.5\%) higher education. Additionally, these last five were the only restaurants supervised by a full-time dietitian.

The hygienic and sanitary conditions of food processing facilities and equipment, and the education level of the people directly involved in food preparation, processing and distribution are critical to prevent most foodborne illnesses. Since the education level of the supervisor of $24.3 \%$ of the restaurants was elementary school, it would be difficult to implement a good food safety management system. According to the MantelHaenszel linear association test results, there was a positive, linear correlation of 0.7005 between the education level of the supervisor and checklist compliance $(p<0.0001)$.

Mortimore ${ }^{17}$ states that the implementation of food safety measures requires skilled people for planning and executing the HACCP. Therefore, food handler selection, training, appropriate education level and competence are required for the production of safe foods.

According to Walker et al. ${ }^{18}$, compulsory HACCP implementation in European food services might be a problem for small and medium-sized establishments that do not have sufficiently educated personnel and have difficulties finding the relevant experts. In Brazil this is less likely because the number of nutrition courses increased significantly, from 45 in 1996 to 329 in $2008^{19}$.

As the food market grows, increasing the competitive advantage by increasing product and/ or service quality is critical for competitiveness. Restaurants should have quality management systems and strive to produce complete, safe, affordable and tasty meals, according to the local food habits and preferences. Because of their professional knowledge, dietitians can help restaurants to improve quality in many ways, especially with regard to production of safe foods.

The checklist was divided into five parts for analysis of the results, namely $A, B, C, D$ and $E$, accordant with the five parts of ISO $22000^{9}$. Figure 1 shows restaurant compliance by group according to checklist section.

Many authors 7,8 reported that there is low adherence to Brazilian standards, especially because of hazardous building layouts.

Obviously, a stricter standard would not ensure better short-term compliance. However, the ISO standards do not make more requirements; they introduce new concepts for their criteria. They explore the need of dietitians to commit to process monitoring and improvement ${ }^{9,10}$.

Restaurants supervised by a full-time dietitian were more compliant with ISO 22000.

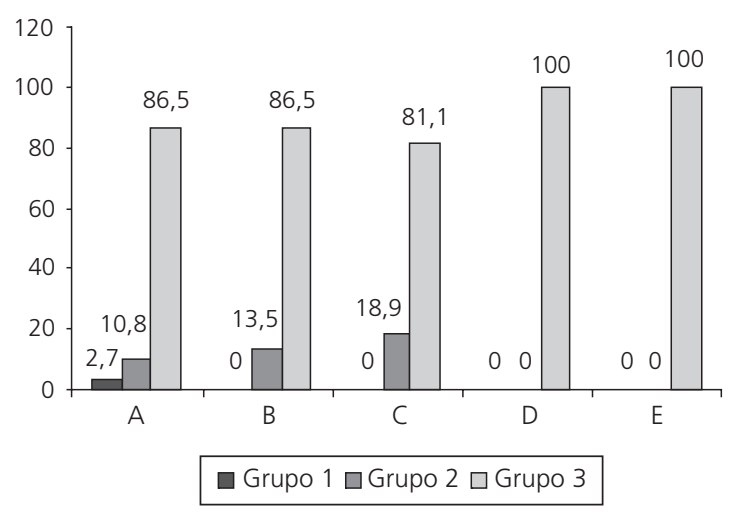

Figure 1. Classification of the restaurants using the ISO 22000 checklist for the five sections: $A=$ food safety system, $\mathrm{B}=$ management responsibility, $\mathrm{C}=$ resource management, $\mathrm{D}=$ planning and making safe products, $\mathrm{E}=$ validation, verification and improvement of the food safety system. 
According to the Mantel-Haenszel linear association test $^{16}$, there was a positive association between meal production supervised by a full-time dietician and compliance $(p<0.0001)$.

The 32 restaurants classified as G3 with respect to Part $B$ (manager responsibilities) did not have a full-time dietitian supervising meal production or appropriate conditions. A study published in 2005 by Akutsu et al. ${ }^{20}$ reported that restaurants without full-time dietitians had poor conditions, with $83.3 \%$ of them classified as G3.

Regarding Part C (food safety requirements), the 7 restaurants classified as G2 had fancy dining rooms, utensils, beverages, menu items and waiter uniforms, showing that these establishments invested in these items. However, meal preparation hygiene was less than ideal, as shown by low compliance with Part D (food safety requirements) of the checklist.

Akutsu et al. ${ }^{20}$ also found a positive relationship between full-time dietitian and GMP implementation: $93.3 \%$ of restaurants without a full-time dietitian and $100.0 \%$ of hotel restaurants without a full-time dietitian were classified as G3, whereas $90 \%$ of the restaurants with a full time dietitian were classified as G2 and $10 \%$ as G1.

Nine restaurants with full-time dietitians had the GMP in place and respective compliance was verified on site. However, according to ISO 22000 Part D9 ${ }^{9}$, full GMP compliance does not ensure safe foods, since HACCP is also required in all food-handling stages, from ingredients to final products. Since ISO 22000 is very complex, it is understandable that $100 \%$ of the restaurants are classified as G3. However, full compliance is not impossible since some Brazilian food services supervised by dieticians have achieved certification.

The second checklist was also divided into parts, namely A, B, C, D, E and F, accordant with the six ISO $14001^{10}$ sections. All restaurants were classified as $\mathrm{G} 3$ with respect to all sections of the standard. Direct observation revealed that the restaurants had no environmental concerns or compliance with the Brazilian law ${ }^{21}$ that determines separation of recyclable and disposable waste.
Only 11 restaurants (29.7\%) had implemented a system for separating recyclables from non-recyclables, and disposed of cooking oil and kitchen grease correctly. Furthermore, none of the restaurants managed their resources properly, wasting food, water and electricity, or controlled the emission of air pollutants. They also failed to comply with other items of the standard. Therefore, it is evident that more environmental education programs are needed for the food sector since this sector also pollutes.

According to Mantel-Haenszel's linear association test, there was no association between supervisor education level and compliance with ISO 14001 ( $p=0.6389)$ or full-time dietitian supervision and compliance with ISO 14001 $(p=1.0000)$.

In today's global economy, organizations are increasingly forced to manage their environmental, social and economic assets correctly ${ }^{22}$. This is because people are increasingly aware of environmental and public health hazards ${ }^{23}$. Today, environmentally-friendly products and processes make companies stand out from their competitors, giving them competitive advantages in domestic and international markets ${ }^{24}$.

According to the Brazilian Technical Standards Association (ABNT) ${ }^{25}$, Brazil ranked eleventh worldwide in 2005 in number of ISO 14001 certifications. Mendonça ${ }^{26}$ published the percentage of certifications issued in Brazil by sector. The foods and beverages sector received $3 \%$ and service providers $8 \%$ of all certifications ${ }^{26}$.

The results of this study showed that the restaurants in Brasilia had no concern for the environment. This may be due to the lack of environmental and sanitary regulations for food services. These conclusions are based on the results of the two checklists. Food safety, represented by the first checklist, is regulated by law and subject to more frequent municipal and state surveillance, so there was higher compliance to it and likelihood of trained professional supervision. 
On the management of solid wastes produced by restaurants, Kinasz ${ }^{27}$ stated that food services should be as concerned with the environment as they are with the production of quality meals, and implement practices and processes that are environmentally friendly, since they pollute the environment and use natural resources in their production processes just like any other organization.

Gadotti $^{28}$ noted that the apparent lack of concern for the environment does not entail punishment but the pollution issue involves more than just actions: it involves ethics, responsibility towards the environment, citizenship, and respect for others. The importance of environmental education is obvious, since it makes people locally and globally aware of their rights and duties and promotes changes that create holistic mindsets.

Kinasz \& Werle ${ }^{29}$ point out that when dietitians and others in managerial positions develop technical and administrative processes, they need to rethink their concepts and attitudes with respect to solid waste management. They need to implement environmentally-friendly food production, distribution and consumption practices and solid waste management. Technical, administrative and operational meal production and distribution regulations must be prioritized. Their aims should be not only to cut costs, improve quality and ensure customers' health and satisfaction, but also to strive to produce less solid waste by minimizing inefficient resource use, helping to reduce the country's environmental problems.

\section{CONCLUSION}

The objectives of this study were achieved since FSMS and EMS assessment showed that the restaurants in Brasilia did not produce safe meals or try to reduce the environmental impact of their wastes. Restaurants with a full-time dietitian are better equipped to produce safe meals. This shows the importance of having trained professionals supervising food handlers and ensuring food safety.
Importantly, the reference instruments (ISO 14000 and 22000) are more difficult to implement than the domestic food safety laws, so there was low ISO compliance and, consequently, most units were classified as G3.

More environmental education programs are necessary in this sector, as well as in the general Brazilian society, to reduce their environmental impact.

This study increases the scope of discussions regarding dietitians' role in restaurants, food safety and environmental impact of food away from home.

\section{CONTRIBUTIONS}

All authors participated in all stages of the research and writing of the article.

\section{REFERENCES}

1. Newell DG, Koopmans M, Verhoef L, Duizer E, Aidara-Kane A, Sprong $\mathrm{H}$, et al. Food-borne diseases: the challenges of 20 years ago still persist while new ones continue to emerge. Int J Food Microbiol. 2010; 139(1):S3-S15.

2. Silva $V$, Amaral AMP. Segurança alimentar, comércio internacional e segurança sanitária. Inf Econ. 2004; 34(6):38-49.

3. Santana NG, Almeida RCC, Ferreira JS, Almeida PF. Microbiological quality and safety of meals served to children and adoption of good manufacturing practices in public school catering in Brazil. Food Control. 2009; 20(3):255-61.

4. Tuominen P, HielmI S, Aarnisalo K, Raaska L, Maijala $R$. Trapping the food safety performance of a small or medium-sized food company using a risk-based model. The HYGRAM ${ }^{\circledast}$ system. Food Control. 2003; 14(8):573-8.

5. Popkin BM. Technology, transport, globalization and the nutrition transition food policy. Food Policy. 2006; 31(6):554-69.

6. Sundkvist A, Milestad R, Jansson AM. On the importance of tightening feedback loops for sustainable development of food systems Food Policy. 2005; 30(2):224-39.

7. Quintiliano $C R$, Santos $T A$, Paulino TST, Schattan RB, Gollücke APB. Avaliação das condições hi- 
380 | LL SANTOS et al.

giênico-sanitárias em restaurantes, com aplicação de ficha de inspeção baseada na legislação federal, RDC 216/2004. Hig Aliment. 2008; 22(160):25-30.

8. Stangarlin L, Delevati MTS, Saccol ALF. Avaliação da implementação do manual de boas práticas e procedimentos operacionais padronizados em serviços de alimentação: II parte. Hig Aliment. 2009; 23(168/169):24-7.

9. Associação Brasileira de Normas Técnicas. NBR ISO 22000: sistema de gestão de segurança de alimentos - requisitos para qualquer organização na cadeia produtiva de alimentos. Rio de Janeiro: ABNT; 2006.

10. Associação Brasileira de Normas Técnicas. NBR ISO 14001: sistema de gestão ambiental - requisitos com orientações para uso. Rio de Janeiro: ABNT; 2004.

11. Poumeyrol G, Rosset P, Noel V, Morelli E. HACCP Methodology implementation of meat pâté hazard analysis in pork butchery. Food Control. 2010; 21(11):1500-6

12. Pasquali L. Tests for the construct: theory and model construction. In: Psychological instruments: practical handbook of elaboration. Brasília: Labpam; 1999.

13. Associação Brasileira de Bares e Restaurantes. 2010 [acesso 2010 fev 14]. Disponível em: <http://www. abrasel.com.br/>.

14. Cochran WG. Sampling Techniques. $3^{\text {rd }}$ ed. New York: John Wiley; 1977.

15. Ministério do Trabalho e do Emprego. Programa de alimentação do trabalhador: legislação. $4^{a}$ ed. Brasilia: MTE; 2006.

16. Stokes ME. Categorical Data Analysis using SAS system. $2^{\text {nd }}$ ed. Cary: SAS Institute Inc; 2000.

17. Mortimore $S$. An example of some procedures used to assess HACCP systems within the food manufacturing industry. Food Control. 2000; 11(5): 403-13.

18. Walker E, Pritchard C, Forsythe S. Hazard analysis critical control point and prerequisite programme implementation in small and medium size food businesses. Food Control. 2003; 14(3):169-74.
19. Akutsu, RC. Brazilian dieticians: professional and demographic profiles. Rev Nutr. 2008; 21(1):7-19. doi: 10.1590/S1415-52732008000100002.

20. Akutsu RC, Botelho RA, Camargo EB, Sávio KEO, Araújo WC. Adequacy of good manufacturing procedures in foodservice establishments. Brazilian J Nutr. 2005; 18(3):419-27.

21. Brasil. Câmara Legislativa do Distrito Federal. Lei $n^{\circ} 3.890$, de 7 de julho, 2006. Dispõe sobre a coleta seletiva de lixo no âmbito do Distrito Federal e dá outras providências. Diário Oficial do Distrito Federal. 200611 jul.

22. Yang C, Lin S, Chan Y, Sheu C. Mediated effect of environmental management on manufacturing competitiveness: an empirical study. Int J Prod Econ. 2010; 123(1):210-20

23. Santangelo A, Albani S, Beretta M, Cappello A, Mamazza G, Pavano $S$, et al. Aging and environmental factors: an estimation of the health state of the elderly population residing in industrialized vs rural áreas. Arch Gerontol Geriatr. 2010; 52(2):181-4.

24. Jorgensen TH, Remmen A, Mellado MD. Integrated management systems: three different levels of integration. J Cleaner Prod. 2006; 14(8):713-22.

25. Associação Brasileira de Normas Técnicas. Rio de Janeiro: ABNT; 2008 [acesso 2008 fev 16]. Disponível em: <http://www.abnt.org.br>.

26. Mendonça RO. Instituto Nacional de Metrologia, Normalização e Qualidade Industrial. Rev Meio Ambient Ind. 2006; 15(1):1-10.

27. Kinasz TR. Reflexão teórica sobre gerenciamento de resíduos sólidos em unidades de alimentação e nutrição. Nutr Pauta. 2007; 15(87):56-60.

28. Gadotti M. Perspectivas atuais da educação. Porto Alegre: Artmed; 2000.

29. Kinasz TR, Werle HJS. Produção e composição física de resíduos sólidos em alguns serviços de alimentação e nutrição nos municípios de Cuiabá e Várzea Grande - Mato Grosso: questões ambientais. Rev Hig Aliment. 2006; 20(144):64-71.

Received on: 14/7/2011

Final version on: 4/5/2012

Approved on: 16/5/2012 